\title{
STREET FOOD: A TOOL FOR PROMOTING TRADITION, TERRITORY, AND TOURISM
}

\author{
SIMONA ALFIERO, ${ }^{*}$ ALESSANDRO BONADONNA, ${ }^{*}$ MASSIMO CANE, * \\ AND AGATA LO GIUDICE† \\ *Department of Management, University of Torino, Torino, Italy \\ $\dagger$ Department of Quality and Operations Management, University of Johannesburg, South Africa
}

\begin{abstract}
Around 2.5 billion people worldwide consume street food every day, thanks to it being low cost, easily available, and convenient. Street food also has high socioeconomic value, as it fosters preservation of the local cultural and food heritage, resulting in increased benefits from tourism and strengthened links with the territory. Two street food operators were reviewed, using the Business Model Canvas (BMC), to investigate street food in Italy and draw public attention to the current situation, highlighting what is needed to counteract flattening of flavors, to promote tourism and safeguard local identity. This initial study aims to identify the unique aspects of the street food business and to describe its close links to its surroundings.
\end{abstract}

Key words: Street food; Outdoor market; Tradition; Territory; Tourism

Introduction

Current economic and cultural innovation is leading stakeholders towards consumption patterns aimed at satisfying both material and immaterial needs. At the same time, new ways of selling food are bringing producers and consumers closer together, enhancing the link with the local area.

The Food and Agriculture Organization of the United Nations (FAO), describes street food as "food and drinks ready for consumption, prepared and/or sold by professionals or traders, mainly on the public roads and other similar places" (FAO, 1997). However the World Health Organization (WHO) classifies food based on the place where it is prepared: "prepared in traditional shops and laboratories," "prepared at home," "prepared in markets," and "prepared on the street" (WHO, 2010). In practice, it is usually meant to include all food ready for fast and immediate consumption, while standing, sitting, or even walking. Also, it is generally sold in single-serve portions, contrary to restaurants, because it is prepared and sold by street vendors at a specific point of sale in a public place, or by mobile 
vendors only on special occasions such as village trade fairs, festivals or open-air concerts.

Some 2.5 billion people worldwide consume street food every day, because of its low cost, easy availability, and convenience. Street food is of high socioeconomic value, as it contributes to preserving the culture and food heritage of a place, with benefits also in terms of increased tourism, as it attracts those wanting to enjoy the flavors of local gastronomic specialties.

On the downside, in some cases street food tends to lose the local identity and become impoverished in terms of diversification of preparations, as well as decline in health and hygiene standards. Globally, WHO sets five rules of health and hygiene for the street food sector, stressing the importance of: 1) "keeping clean," 2) "separating raw from cooked foods," 3) "cooking in the correct way," 4) "keeping food at a safe temperature," and 5) "using water and safe raw materials" (WHO, 2006). These five rules are crucial, as the method and place of preparation do not always comply with even the most basic rules of hygiene and safety.

Many studies in street food (Alonso, Sakellarios, \& Bressan, 2017; Atadil, Sirakaya-Turk, Meng, \& Decrop, 2018; Azanza, Gatachalian, \& Ortega, 2000; Liu, Zhang, \& Zhang, 2014; Sabbithi et al., 2017; Zhou, Qu, \& Li, 2016) have indicated that not enough attention is paid to hygiene and safety.

As demonstrated by Alfiero, Lo Giudice, and Bonadonna (2017), compliance with hygiene requirements (including equipment and availability of basic services) is an ingredient for the success of commercial food truck services.

This work investigates various business models in an effort to explain the features of street food and draw public attention to it, highlighting what contributes to counteracting the general trend to flattening of flavors and to developing tourism while safeguarding local identity.

Street food is influenced by local culture and social context, and this study analyzes and compares two businesses operating in as many different locations, highlighting their individual characteristics.

The preliminary results of an ad hoc questionnaire are illustrated. Two street food operators were selected based on specific parameters including length of activity in the market, type of products offered, place of preparation, and point of sale.

\section{Literature Review}

\section{Street Food}

In the last decade food sector competitiveness has been growing consistently, due in part to continuous and rapid changes in lifestyle and consumer habits - interest in street food being an example of how these changes can alter behavior patterns and diets.

Street food has high social and economic value (FAO, 2009; Tinker, 1999) and is useful for 1) safeguarding cultural and social heritage (Alves da Silva et al., 2014; Long-Solís, 2007), 2) stimulating and promoting tourism (Privitera, 2015; Steyn \& Labadarios, 2011; Wei, 2015), and 3) offering new opportunities for entrepreneurship and income all over the world (Caramaschi, 2017; FAO, 2009).

A risk for food safety is diet. The contribution of street food in terms of calories and nutrients is crucial, especially in developing countries (Blair, 1999; Ekinci, Sirakaya-Turk, \& Prediado, 2013; FAO, 1997; Khairuzzaman, Chowdhury, Zaman, Mumun, \& Bari Md, 2014; Pappas, 2016) but also in Europe (Darmon, 2009).

Some characteristics of street food are similar throughout the world. It is 1) ubiquitous - 2.5 billion people consume street food every day worldwide because of low cost and convenience (FAO, 2012), 2) vital - continuously increasing, providing entrepreneurial opportunities with low initial capital investment, 3) accessible - for fast consumption, practical, and cheap, and 4) sustainable - often prepared with fresh and local ingredients.

In Europe, the popularity of street food has resulted in the appearance of a growing number of fast food outlets like the Dutch FEBO in town centers and markets of cities like Palermo and Florence, selling sandwiches with "lampredotto" or "milza" (spleen). This development is ongoing (Basinski, 2014), linking diversified traditions (e.g., the kebab, the typical Mediterranean street food which has become immensely popular in the last decade).

\section{Development of Street Food}

In the last 10 years street food has been a food service, characterized by strong local values. The cities of the north saw the rise of vans waiting on 
street corners to meet the food needs of night owls and party goers.

In central and southern areas street food became an integral part of the social and cultural fabric of local communities. Examples of this include the Florentine "lampredotto," the "pani ca "Meusa" of Palermo, the "Ascolan olives," the "rustic salentini," and the "Cuoppo Fritto" of Naples.

A study by Coldiretti (2016) points to a record growth of street food by $+13 \%$, mostly between 2015 and 2016, with more than 2,200 businesses involved in the preparation of ready-to-eat food (market or mobile based). In the same period, two out of three consumers bought street food, $81 \%$ of them purchasing local traditional food, $13 \%$ opting for international products, and $6 \%$ going ethnic. The same study highlighted a loss of local identity, impoverished diversification of preparations, and, in some cases, a decline in health and hygiene (Coldiretti, 2016).

The reasons for the success of street food seem to be a continuous search by discerning consumers for high-quality ingredients and a change in the pace of life, which became increasingly frenetic, accompanied by reduced rest breaks at work and less disposable income.

\section{Street Food and Tourism}

Italy has a long tradition of catering services available "on the street." In particular, street food services are popular at open-air concerts and/or sporting events, as a substitute for conventional food services, as part of the nightlife scene, as well as at industrial plants on working days in daylight hours. Trucks are normally set up to offer this service and can be either "Traditional Food Trucks" (TFTs) or "Gourmet Food Trucks" (GFTs). TFTs are trucks or other vehicles in a public space equipped for preparing and handling food. The menu consists of low-cost fast food such as hot dogs, sausages, and precooked vegetables.

In the last decade a new type of food truck has been introduced-GFTs aimed at the more sophisticated customers expecting better quality, selected raw materials, attractive presentation, and traditional revisited recipes (Alfiero et al., 2017; Alfiero, Wade, Taliano, \& Bonadonna, 2018). Apart from the food services served from a truck, there are other options for providing food to consumers out walking, such as pizzerias serving sliced pizza, ice cream parlors, or traditional roast chestnut vendors.

Street food can also be seen as a means for attracting tourists. The increased demand for quality and traditional street food has brought about an increase in the number of dedicated gastronomic events in the last 5 years, from 9 events in 2013 to 27 in 2014, up to 55 in 2017, based on information available online (streetfood.it, streeatfoodtruckfes tival.com, facebook.com, foodtruckfest.it).

The Food Truck Fest attracted 15,000 visitors, whereas the media estimated 60,000 people/event for Streetfood.it, 100,000 people/event for the International Street Food Parade and for the Street Food Truck Festival (Table 1). This seems to confirm the value of street food events in terms of tourist attraction.

\section{Methods}

Based on the above information, the street food situation has been reviewed through a comparison between north and south, which differ as regards regional interpretation of this particular food service.

Table 1

Number of Events in Italy by Organization

\begin{tabular}{lcccccc}
\hline & 2017 & 2016 & 2015 & 2014 & 2013 & Persons/Event \\
\hline StreetFood Truck Festival & 11 & 11 & 11 & 2 & - & 100,000 \\
International Street Food Parade & 10 & 10 & 4 & 1 & - & 100,000 \\
Streetfood.it & 24 & 25 & 31 & 24 & 9 & 60,000 \\
Food Truck Fest & 10 & 7 & 4 & - & - & 15,000 \\
Total & 55 & 53 & 50 & 27 & 9 & 275,000 \\
\hline
\end{tabular}

Source: Authors' elaboration based on information available online (streetfood.it, streeatfoodtruck festival.com, facebook.com, foodtruckfest.it). 


\section{Street Food Operators}

The multiple case method used involved first selecting the operators, followed by highlighting the relative differences in service development and subsequently comparing differences within the study group (Baxter \& Jack, 2008). This method explains the dynamics within a single context (Eisenhardt, 1989). The case studies offer insights otherwise not necessarily apparent (Rowley, 2002). Subsequently, we used different parameters to identify two market operators who had only recently entered the street food business in the country.

The first parameter was the time spent working in the street food market (18-24 months). This time frame was considered essential to evaluate operators with little experience in the street food sector but whose business could be considered profitable shortly after starting.

The second parameter was the type of product offered, the idea being to identify two operators who had the same product category as a main ingredient of their menu and who integrated the concept of tradition and local area in their philosophy.

The third parameter was the point of sale and its features. The first aspect was geographical location based on the assumption that there are conceptual differences between north and south. The second aspect related to tourism and therefore the point of sale had to be situated near an adequate flow of tourists. Food trucks were excluded because, although from the most populated category of operators in the street food service, they did not feature a single point of sale and would not have fulfilled the need for a well-defined location. The two case studies selected for the research were evaluated using various sources (Eisenhardt, 1989), including online (company website, reports, etc.).

The combined parameters pointed to two operators whose catchment area was near two markets benefiting from a steady flow of tourists, although not necessarily recognized as such, when compared with that of major tourist cities (i.e., Rome, Venice, and Florence). The markets in question were Porta Palazzo, the main market of Turin, and 'A Piscaria, the fish market of Catania. The product category chosen was fish products because both markets have seen the addition of two new street food businesses over the last 24 months that have proved commercially successful. The Turin business was La Pescheria di Beppe Gallina (PBG), ideally located in the farmers' market on the northeastern side of Porta Palazzo, and the Catania business was the Scirocco Sicilian Fish Lab (SSFL), run by Marco Timpanaro, directly overlooking the fish market 'A Piscaria.

\section{Study Areas}

Porta Palazzo Market. Porta Palazzo is the largest market in Turin (Alfiero et al., 2017; Black, 2012; Gilli \& Ferrari, 2018; Peira, Bollani, Giachino, \& Bonadonna, 2018), the city of the Salone del Gusto and Terra Madre, slow food's most famous events (Hendrikx, Dormans, Lagendijk, \& Thelwall, 2017; Myers, 2013), and Eataly (Bertoldi, Giachino, \& Stupino, 2015; Sebastiani, Montagnini, \& Dalli, 2013), the only Italian distribution chain of national high-quality foodstuff with supermarkets all over the world.

The Porta Palazzo market is open for business daily from Monday to Friday from 7:00 am to 2:00 pm and Saturdays from 7:00 am to 7:00 pm, with more than 1,000 itinerant stalls. It was moved to its current location on August 29, 1835, having received a church ruling, after an outbreak of cholera, that prohibited the sale of food products in the "Palazzo di Città" square (at the time "Delle Erbe") and "Corpus Domini" square, home to Turin's main market since the Middle Ages. First, two canopies were built and then rows of shacks were set up for the markets of fabrics, trinkets, and earthenware. The icehouses for food storage were located underground below the square, accessed by carts carrying ice produced from snow collected in the town, except in mild winters and during periods of short supply of snow when it was transported from the mountain region of Moncenisio.

Porta Palazzo is an alternative trading system to large-scale retail trade that provides a choice of products from different product categories. It is estimated that there are 100,000 visitors a week with 25,000 on Saturdays. The food section includes the outdoor fruit and vegetable market with 276 stalls, the IV food market (called Tettoia dell'Orologio) with 78 stalls, the $\mathrm{V}$ food with 
40 stalls, the fish market with 15 stalls, and the Farmers' Market (called Tettoia dei Contadini) with 69 operators.

The 'A Piscaria Market. The archaeological city of Catania near the Etna volcano (Mentesana, De Benedetto, \& Fiorentino, 2018) has alternative food outlets (Scuderi, Bellia, Foti, Timpanaro, \& Sturiale, 2016; Scuderi, Foti, \& Stella, 2018) and vocational tourist attractions (Privitera, 2015; Privitera, Nedelcu, \& Nicula, 2018).

There are two typical historical markets in Catania: the 'A Piscaria and the Fera du' Luni. They are both located in the heart of the city albeit with some differences. Over the years, the 'A Piscaria has maintained the features of a traditional market and is still managed by locals selling mainly "traditional" food. The Fera du' Luni is managed by locals and by people from different countries who have brought in new products including food. Consequently, the latter is more similar to other Italian markets such as that of Piazza Vittorio in Rome or Porta Palazzo in Turin.

In particular, the 'A Piscaria (literally the "fish market") is one of the most significant landmarks in the city. The market is located between the harbor and the city center, just off Piazza Duomo (Catania's main square), and was originally closer to the seashore before a landfill operation changed the city's layout. Opening days are Monday to Saturday, usually between 8:00 am and 2:00 pm. Produce include a wide selection of local fish and durables. Over the years numerous food outlets settled around A' Piscaria, including taverns, restaurants, and, more recently, street food vendors.

The market area comprises two main squares, namely Piazza Alonzo Di Benedetto (Fishermen's Square) and Piazza Pardo (Fishmongers' Square). Piazza Di Benedetto is the main market square and lifeblood with fishermen busy selling the fish they catch themselves. Close to it is Piazza Pardo where fishmongers (retailers) keep stalls: according to Marovelli (2016), there are 12 fishmongers' stalls in the square.

The market also has shellfish stalls next to the fishmongers. There are 6 quite small shellfish stalls (Marovelli, 2016), made up of steel drums full of water, where shellfish are kept alive. Some are fished locally and the rest arrives from the Adriatic Sea or France.

\section{Interviews and Questionnaire}

To gather the information needed, a semistructured interview was chosen in line with Alvesson (2003). The first interview was held on October 12, 2017 regarding PBG, and the second on November 10, 2017 on SSFL. Interviewees included owners and managers of the two businesses, interviews lasting $48 \mathrm{~min}$ and $1 \mathrm{hr} 17 \mathrm{~min}$, respectively.

The purpose was to collect all information needed to assess the features of each business model (Fideli \& Marradi, 1996; Pitrone, 1984). We visited both companies before conducting interviews onsite. Subsequently, we analyzed results separately to avoid influencing one other (Atkinson \& Shaffir, 1998). Each analysis and the fundamental elements identified were then compared.

There were three parts to each interview. The first was a description of the company and family background, its business philosophy and core business, managerial and organizational aspects, and different approaches to integrating the concept of innovation and tradition into the company philosophy.

In the second part the interviewees were asked to describe the strengths, weaknesses, opportunities, and challenges of the street food business and the concepts of innovation and tradition, and whether street food was a driver for local tourism.

The third part asked for information on street food menus, with number of products on offer, their description, and pricing. Owners were asked to describe the type/purpose of their street food business according to key parameters (traditional, innovative, necessary, fashionable, effective, tourist, local area/catchment area/local demographics, meeting market demand). Finally, questions were asked about the relationship between street food and incidence of tourism, the city, season, competition, location, and cultural contamination. To achieve objectives, a review of outputs was made to spot any differences in the approach to street food in two cities.

\section{The Business Model Canvas}

To prepare the questionnaire for subsequent comparison of the two operators selected, we decided to adopt the business analysis model 
(Zott, Amit, \& Massa, 2011) known as Business Model Canvas (BMC) (Osterwalder \& Pigneur, 2010) which defines eight dimensions and highlights the main characteristics of each business.

BMC explains the strategy to create value by enterprise (Osterwalder \& Pigneur, 2010). The object of a business model is to stimulate the sharing of information to create a communication advantage and increase knowledge about the processes involved at all organizational levels.

$\mathrm{BMC}$ is a visual language made up of blocks, each a fundamental element of enterprise: value propositions, key resources, key activities, key partners, customer segments, customer relationships, channels, cost structure, and revenue streams.

$\mathrm{BMC}$ is a useful support tool for entrepreneurial initiatives in education (Zeng \& Honig, 2016), to enhance students' business initiatives (Haertel, Terkowsky, \& May, 2016) towards team collaboration (Neumeyer \& McKenna, 2016) and to transfer business knowledge (Jackson, Scott, \& Schwagler, 2015). It is also considered a tool for organizing university planning (Rytkönen \& Nenonen, 2014) and healthcare sector planning (Qushem, Dahlan, \& Ghani, 2016).

$\mathrm{BMC}$ is a tool for helping small and medium enterprises (SMEs) to manage the critical phase of "grow or die" (Frick \& Ali, 2013) and startups (Ojasalo \& Ojasalo, 2016), as well as assessing the evolution of SMEs (Jingga \& Limantara, 2015), and comparing small business activities or students' perception by means of other technical tools (Osterwalder \& Pigneur, 2010; Türko, 2016).

BMC has been applied in the food sector: improving sustainable development (Rivera \& Hoyos Concha, 2016), supporting the protection and maintenance of acquired advantages and competitiveness (Dudin, Lyasnikov, Leont'eva, Reshetov, \& Sidorenko, 2015; Pokorná, Pilar, Balcarová, \& Sergeeva, 2015), implementing and developing products and complementary services (Cantino, Alfiero, Cane, \& De Bernardi, 2016; Martikainen, Niemi, \& Pekkanen, 2014).

In line with some authors (Baldassarre, Calabretta, Bocken, \& Jaskiewicz, 2017; Bocken, Rana, \& Short, 2015), we believe BMC could be applied not only to one kind of stakeholder (i.e., the customer) but also to the environment and society. This approach would provide a more accurate assessment of value proposition carried out by street food operators.

\section{Results}

BMC and its seven dimensions of analysis were used, focusing on entrepreneurial issues of small businesses such as those described in this article, but it was not possible to reconstruct their cost structure or revenue streams. However, the research helped highlighting those elements that characterize the two operators' businesses (i.e., the aspects they had in common and those that were different), also considering the operating conditions of each locality. The considerations for each dimension of analysis are detailed below.

\section{Value Propositions}

One of the main differences between the two operators emerged from the different choices in terms of value proposition. PBG's street food business developed gradually alongside its original business of selling raw fish products. The key idea was to have people try dishes at the same point of sale as the raw ingredients used in their preparation. This new concept benefited significantly from the strong and established identity and reputation of selling fish locally. SSFL, on the other hand, started purely as a street food operator, which was probably an advantage as in southern Italy street food culture was already established.

\section{Key Resources}

Both operators mostly relied on top quality fish products, strategically located points of sale, and strong family traditions. In SSFL's case, staff were trained to serve tourists and international visitors, considered to be a strategic asset.

\section{Key Activities}

The two vendors are very different. Selling fish products was still PBG's core business, street food 
taking second place, whereas SSFL only sold street food.

\section{Key Partners}

Both key partners shared the importance of establishing good relations with direct suppliers of raw fish products, although they differed in other respects. PBG's strengths included trusted staff, acclaimed/top chefs, and organized events. SSFL partnered with packaging and know-how experts and drinks suppliers.

\section{Customer Segments}

PBG's main clientele included customers of Porta Palazzo market, which is where the business is located and passers-by and tourists are a secondary factor. SSFL focused on the regular flow of tourists typical of Catania's fish market.

Table 2

Summarized Early Results of the Research

\begin{tabular}{ll}
\hline & La Pescheria di Beppe Gallina (PBG) \\
\hline $\begin{array}{l}\text { Value propositions: The value proposi- } \\
\text { tions are those products and services that } \\
\text { represent a value associated to a specific } \\
\text { client segment. }\end{array}$ & $\begin{array}{c}\text { Direct sales of raw material; Zero km } \\
\text { take aways }\end{array}$ \\
$\begin{array}{ll}\text { Key resources: These include strategic } \\
\begin{array}{l}\text { assets the company needs in order to start } \\
\text { and maintain its business model. }\end{array}\end{array}$ & $\begin{array}{l}\text { Family support and experience; } \\
\text { Top quality raw materials (fish } \\
\text { products); Strategic positions for } \\
\text { points of sale } \\
\text { Business talent }\end{array}$ \\
\end{tabular}

Key activities: These activities describe those tasks which must be carried out in order to create and sustain the value propositions, reach customers, maintain good relations with them and generate income.

Key partners: This part defines the network of suppliers and partners necessary for the correct workings of the business model.

Customer segments: This part covers the different groups of people and/or organizations that make up the company's target.

Customer relationships: This part describes the type of relationship the company establishes with certain types of customer. For example, how a company: acquires new customers, gets them to keep coming back, increases sales.

Channels: This part describes how the company reaches a certain segment of clientele in order to present and sell them its proposition of value.
Sales of raw materials; Food outlet (fishmongers/take away/street food)

Trusted direct suppliers (e.g., Ligurian fishermen); Regular and trusted staff;

Partnership with prestigious chefs and organized events

Market goers; Tourists (especially in summer)

Try to make customers regular; Good local reputation (Maestro del Gusto/ Slow Food)

Presence in tourist and "foodies" guides; Website; Social network; Situated on the edges of the Porta Palazzo market; Word of mouth
Family support and experience; Top quality raw materials (fish products); Strategic positions for points of sale; Business skills and training; Staff training - foreign language and people skills for staff serving customers and practical, work experience for cooks

Food outlet (Street Food)

Trusted direct suppliers (fish market); Consultancy to define the business and determine the menu; Packaging suppliers; Drinks suppliers

Tourists

Partnerships with local accommodation facilities; Strategically placing points of sale in touristy locations; Promotions

Social network; Website; Presence in tourist and "foodies" guides; Situated in the fish market, near the port (where cruises dock), busy thoroughfare; Word of mouth

Source: elaborated by the authors. 


\section{Customer Relationship}

PBG's success in turning the local clientele into regular customers was fundamental, from the early days when they only sold fish, to later when they started selling street food. This ability to attract and consistently satisfy their customers was probably also helped by winning recognition from the Chamber of Commerce in Turin, Slow Food, and the title of Maestro del Gusto. Strategically located points of sale and targeted marketing with local accommodation facilities were all fundamental for SSFL in order to tap into the constant flow of tourists.

\section{Channels}

To reach their target customers, both businesses used a number of different communication channels, including the main tourist and "foodies" guides, social media, websites, word of mouth, and their all-important strategic location. Results are summarized in Table 2.

\section{Conclusions}

This article is phase one of a comprehensive, in-depth study aimed at identifying the unique aspects of selected street food operators; analysis of the business models enabled us to recognize critical success factors. One of the first features to emerge was the fact that the street food business is linked to its surrounding area, the main driver of success being locally sourced raw materials and strategically located points of sale. This gives wider meaning to the term "street," encompassing not only food eaten in public, but also local cultural and knowledge-based tradition: distinguishing characteristics highlighting the main differences between operators' business models. However, the local area and its top quality products and tradition are not sufficient by themselves to ensure sustainability to the street food business; sound managerial skills are also needed. The ability to set up partnerships with suppliers, secure customer loyalty, invest in staff training, and broaden communication channels are strategic management tools a business must use efficiently to achieve success.

\section{References}

Alfiero, S., Lo Giudice, A., \& Bonadonna, A. (2017). Street food and innovation: The food truck phenomenon. British Food Journal, 119(11), 2462-2476.

Alfiero, S., Wade, B., Taliano, A., \& Bonadonna, A. (2018). Defining the food truck phenomenon in Italy: A feasible explanation. In V. Cantino, F. Culasso, \& G. Racca (Eds.), Smart tourism (pp. 365-385). Milan, Italy: McGraw-Hill Education.

Alonso, A. D., Sakellarios, N., \& Bressan, A. (2017). Stakeholders and craft beer tourism development. Tourism Analysis, 22(1), 45-58.

Alves da Silva, S., Cardoso, R. D. C. V., Góes, J. T. W., Santos, J. N., Ramos, F. P., Bispo de Jesus, R., Sabá do Vale, R., \& Teles da Silva, P. S. (2014). Street food on the coast of Salvador, Bahia, Brazil: A study from the socioeconomic and food safety perspectives. Food Control, 40(1), 78-84.

Alvesson, M. (2003). Methodology for close up studiesStruggling with closeness and closure. Higher Education, 46(2), 167-193.

Atadil, H. A., Sirakaya-Turk, E., Meng, F., \& Decrop, A. (2018). Exploring travelers' decision-making styles. International Journal of Contemporary Hospitality Management, 30(1), 618-636.

Atkinson, A. C., \& Shaffir, W. (1998). Standards for field research in management accounting. Journal of Management Accounting Research, 10, 41-68.

Azanza, M. P. V., Gatchalian, C. F., \& Ortega, M. P. (2000). Food safety knowledge and practices of street food vendors in a Philippines university campus. International Journal of Food Sciences and Nutrition, 51(4), 235-246.

Baldassarre, B., Calabretta, G., Bocken, N. M. P., \& Jaskiewicz, T. (2017). Bridging sustainable business model innovation and user-driven innovation: A process for sustainable value proposition design. Journal of Cleaner Production, 147, 175-186.

Basinski, S. (2014). Hot dogs, hipsters, and xenophobia: Immigrant street food vendors in New York. Social Research: An International Quarterly, 81(2), 397-408.

Baxter, P., \& Jack, S. (2008). Qualitative case study methodology: Study design and implementation for novice researchers. The Qualitative Report, 13(4), 544-559.

Bertoldi, B., Giachino, C., \& Stupino, M. (2015). Innovative approaches to brand value and consumer perception: The Eataly case. Journal of Customer Behaviour, 14(4), 353-367.

Black, R. E. (2012). Porta Palazzo: The anthropology of an Italian market. Philadelphia, PA: University of Pennsylvania Press.

Blair, D. (1999). Street food vending and nutritional impact. Agriculture and Human Values, 16(3), 321-323.

Bocken, N. M. P., Rana, P., \& Short, S. W. (2015). Value mapping for sustainable business thinking. Journal of Industrial and Production Engineering, 32(1), 67-81.

Cantino, V., Alfiero, S., Cane, M., De Bernardi, P. (2016). Business model and value drivers of the chocolate 
district. In M. Sargiacomo (Ed.), Accounting and management of the agribusiness industry (pp. 97-140). Milan, Italy: McGraw-Hill Education.

Caramaschi, S. (2017). Counteracting food deserts. The potential for mobile food vending in regenerating contemporary cities. International Journal of Sustainable Development and Planning, 12(4), 744-751.

Coldiretti. (2016). Cibo di strada tra rischi ed opportunità. Retrieved from http://www.lultimaribattuta.it/ 48396_cibo-strada-rischi-opportunita

Darmon, $\bar{N}$. (2009). A fortified street food to prevent nutritional deficiencies in homeless men in France. Journal of the American College of Nutrition, 28(2), 196-202.

Dudin, M. N., Lyasnikov, N. V. E., Leont'eva, L. S., Reshetov, K. J. E., \& Sidorenko, V. N. (2015). Business model canvas as a basis for the competitive advantage of enterprise structures in the industrial agriculture. Biosciences Biotechnology Research Asia, 12(1), 887-894.

Eisenhardt, K. M. (1989). Building theories from case study research. Academy of Management Review, 14(4), 532-550.

Ekinci, Y., Sirakaya-Turk, E., \& Preciado, S. (2013). Symbolic consumption of tourism destination brands. Journal of Business Research, 66(6), 711-718.

Fideli, R., \& Marradi, A. (1996). Intervista. In Enciclopedia delle Scienze Sociali. Rome, Italy: Istituto della Enciclopedia Italiana.

Food and Agriculture Organization of the United Nations. (1997). Street foods. Retrieved from http://www.fao.org/ fcit/food-processing/street-foods/en/

Food and Agriculture Organization of the United Nations. (2009). Good hygienic practices in the preparation and sale of street food in Africa. Retrieved from http://www. fao.org/3/a0740e/a0740e00.htm

Food and Agriculture Organization of the United Nations. (2012). Selling street and snack foods. Retrieved from http://www.fao.org/docrep/015/i2474e/i2474e00.pdf

Frick, J., \& Ali, M. M. (2013, September). Business model canvas as tool for SME. In IFIP International Conference on Advances in Production Management Systems (pp. 142-149). Berlin, Germany: Springer.

Gilli, M., \& Ferrari, S. (2018). Tourism in multi-ethnic districts: The case of Porta Palazzo market in Torino. Leisure Studies, 37(2), 146-157.

Haertel, T., Terkowsky, M. C., \& May, D. (2016). The shark tank experience: How engineering students learn to become entrepreneurs. Paper presented at the 2016 Annual Conference and Exposition, ASEE, June. Retrieved from https://peer.asee.org/the-shark-tank-experience-howengineering-students-learn-to-become-entrepreneurs

Hendrikx, B., Dormans, S., Lagendijk, A., \& Thelwall, M. (2017). Understanding the geographical development of social movements: A web-link analysis of Slow Food. Global Networks, 17(1), 47-67.

Jackson, W. T., Scott, D. J., \& Schwagler, N. (2015). Using the business model canvas as a methods approach to teaching entrepreneurial finance. Journal of Entrepreneurship Education, 18(2), 99.
Jingga, F., \& Limantara, N. (2015). The development of Indonesia small medium enterprise (SME) rating and review portal. International Journal of Multimedia and Ubiquitous Engineering, 10(3), 211-218.

Khairuzzaman, Md., Chowdhury F. M., Zaman S., Mamun A. A., \& Bari Md. L. (2014). Food safety challenges towards safe, healthy, and nutritious street foods in Bangladesh. International Journal of Food Science, 1-9.

Liu, Z., Zhang, G., \& Zhang, X. (2014). Urban street foods in Shijiazhuang city, China: Current status, safety practices and risk mitigating strategies. Food Control, 41(1), 212-218.

Long-Solís, J. (2007). A survey of street foods in Mexico city. Food and Foodways, 15(3-4), 213-236.

Marovelli, B. (2016). The significance of landscape in a Sicilian food market. Anthropology of Food, 11. Retrieved from https://journals.openedition.org/aof/8062

Martikainen, A., Niemi, P., \& Pekkanen, P. (2014). Developing a service offering for a logistical service providerCase of local food supply chain. International Journal of Production Economics, 157, 318-326.

Mentesana, R., De Benedetto, G., \& Fiorentino, G. (2018). One pot's tale: Reconstructing the movement of people, materials and knowledge in Early Bronze Age Sicily through the microhistory of a vessel. Journal of Archaeological Science: Reports, 19, 261-269.

Myers, J. (2013). The logic of the gift: The possibilities and limitations of Carlo Petrini's slow food alternative. Agriculture and Human Values, 30(3), 405-415.

Neumeyer, X., \& McKenna, A. (2016). Entrepreneurial thinking in interdisciplinary student teams. Advances in Engineering Education, 5(1).

Ojasalo, J., \& Ojasalo, K. (2016). Service logic business model canvas for lean development of SMEs and startups. In Handbook of research on entrepreneurship in the contemporary knowledge-based global economy (pp. 217-243). Hershey, PA: IGI Global.

Osterwalder, A., \& Pigneur, Y. (2010). Business model generation: A handbook for visionaries, game changers, and challengers. Hoboken, NJ: Wiley.

Pappas, N. (2016). Residents' support in major local events: Leeds pride. Tourism Analysis, 21(5), 451-464.

Peira, G., Bollani, L., Giachino, C., \& Bonadonna, A. (2018). The management of unsold food in outdoor market areas: Food operators' behaviour and attitudes. Sustainability, 10(4), 1180.

Pitrone, M. C. (1984). Il Sondaggio. Milan, Italy: Franco Angeli Editore.

Pokorná, J., Pilar, L., Balcarová, T., \& Sergeeva, I. (2015). Value proposition canvas: Identification of pains, gains and customer jobs at farmers' markets. AGRIS on-line Papers in Economics and Informatics, 7(4), 123.

Privitera, D. (2015). Street food as form of expression and socio-cultural differentiation. Paper presented at the 12th PASCAL International Observatory Conference. Catania, October 7-9.

Privitera, D., Nedelcu, A., \& Nicula, V. (2018). Gastronomic and food tourism as an economic local resource: Case 
studies from Romania and Italy. Geojournal of Tourism and Geosites, 21(1), 143-157.

Qushem, U. B., Dahlan, A. R. B. A., \& Ghani, A. S. B. M. (2016). My emergency assistant device: A conceptual solution in enhancing the quality of life for the disabled and elderly. In Information and Communication Technology for the Muslim World (ICT4M) (pp. 82-87). Piscataway, NJ: IEEE.

Rivera, W. F., \& Hoyos Concha, J. L. (2016). Business model for initiatives in science, technology and innovation. An application for the fish agroindustry of cauca. Vitae.

Rowley, J. (2002). Using case studies in research. Management Research News, 25(1), 16-27.

Rytkönen, E., \& Nenonen, S. (2014). The business model canvas in university campus management. Intelligent Buildings International, 6(3), 138-154.

Sabbithi, A., Reddi, S. G. D. N. L., Naveen Kumar, R., Bhaskar, V., Subba Rao, G. M., \& Rao V. S. (2017). Identifying critical risk practices among street food handlers. British Food Journal, 119(2), 390-400.

Scuderi, A., Bellia, C., Foti, V. T., Timpanaro, G., \& Sturiale, L. (2016). The redefinition of the role of agricultural areas in the city of Catania. Rivista di studi sulla sostenibilità, 6(2), 237-247.

Scuderi, A., Foti, V. T., \& Stella, G. (2018). Social farm action value: The case study of "case di maria". Quality Access to Success, 19(S1), 475-481.

Sebastiani, R., Montagnini, F., \& Dalli, D. (2013). Ethical consumption and new business models in the food industry. Evidence from the Eataly case. Journal of Business Ethics, 114(3), 473-488.
Steyn, N. P., \& Labadarios, D. (2011). Street foods and fast foods: How much do South Africans of different ethnic groups consume? Ethnicity and Disease, 21(4), 462-466.

Tinker, I. (1999). Street foods into the 21st century. Agriculture and Human Values, 16(3), 327-333.

Türko, E. S. (2016). Business plan vs business model canvas in entrepreneurship trainings: A comparison of students' perceptions. Asian Social Science, 12(10), 55.

Wei, M. (2015). Construction and evaluation of a performance model of the tourism industry. Tourism Analysis, 20(6), 653-664.

World Health Organization. (2006). Five keys to safer food manual. Retrieved from http://apps.who.int/iris/bitstrea m/10665/43546/1/9789241594639_eng.pdf?ua=1

World Health Organization. (2010). Basic steps to improve safety of street-vended food. Retrieved from http:// www.who.int/foodsafety/fs_management/No_03 StreetFood_Jun10_en.pdf

Zeng, Z., \& Honig, B. (2016). How should entrepreneurship be taught to students with diverse experience? A set of conceptual models of entrepreneurship education. In Models of start-up thinking and action: Theoretical, empirical and pedagogical approaches (pp. 237-282). Bingley, UK: Emerald Group Publishing Limited.

Zhou, B., Qu, H., \& Li, N. (2016). How tourist attraction agglomeration affects a regional tourism economy. Tourism Analysis, 21(6), 603-616.

Zott, C., Amit, R., \& Massa, L. (2011). The business model: Theoretical roots, recent development, and future research. Journal of Management, 37(4), 1019-1042. 